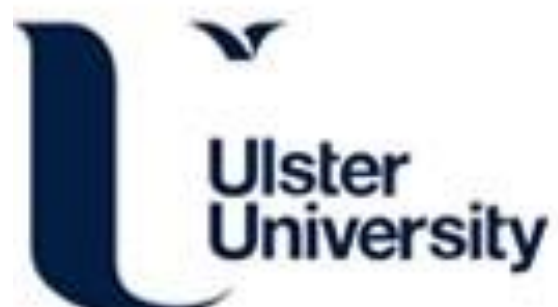

\section{Barriers and Facilitators to Smoking Cessation Among People With Severe Mental Illness: A Critical Appraisal of Qualitative Studies}

Trainor, K., \& Leavey, G. (2017). Barriers and Facilitators to Smoking Cessation Among People With Severe Mental Illness: A Critical Appraisal of Qualitative Studies. Nicotine \& Tobacco Research, 19(1), 14-23. https://doi.org/10.1093/ntr/ntw183

Link to publication record in Ulster University Research Portal

Published in:

Nicotine \& Tobacco Research

Publication Status:

Published (in print/issue): 01/01/2017

DOI:

10.1093/ntr/ntw183

Document Version

Author Accepted version

\section{General rights}

Copyright for the publications made accessible via Ulster University's Research Portal is retained by the author(s) and / or other copyright owners and it is a condition of accessing these publications that users recognise and abide by the legal requirements associated with these rights.

\section{Take down policy}

The Research Portal is Ulster University's institutional repository that provides access to Ulster's research outputs. Every effort has been made to ensure that content in the Research Portal does not infringe any person's rights, or applicable UK laws. If you discover content in the Research Portal that you believe breaches copyright or violates any law, please contact pure-support@ulster.ac.uk. 
See discussions, stats, and author profiles for this publication at: https://www.researchgate.net/publication/305487725

\section{Barriers and Facilitators to Smoking Cessation Among People With Severe Mental Illness: A Critical Appraisal of Qualitative Studies}

Article in Nicotine \& Tobacco Research · July 2016

Dol: $10.1093 / \mathrm{nt} / \mathrm{ntw} 183$

\section{CITATIONS}

11

2 authors:

Katie Trainor

Ulster University

2 PUBLICATIONS 24 CITATIONS

SEE PROFILE

Some of the authors of this publication are also working on these related projects:

GIFTS (Gender Identity Finding and Transforming Services) View project

Project

Needs Assessment of Vulnerable Young Men View project
216

Gerard Leavey

Ulster University

169 PUBLICATIONS 2,544 CITATIONS

SEE PROFILE 
Nicotine \& Tobacco Research Advance Access published July 20, 2016

\title{
Barriers and facilitators to smoking cessation among people with severe mental illness: A critical appraisal of qualitative studies
}

\begin{abstract}
Authors
Katie Trainor, MRes, BSc Psychology (Hons) University of Ulster, Faculty of Life and Health Sciences, Health and Life Sciences, Coleraine, UK BT52 1 SA.

Professor Gerard Leavey, Ph.D. Director - The Bamford Centre for Mental Health and Wellbeing. Clinical Lead - NI Clinical Research Network (Mental Health). University of Ulster Faculty of Life and Health Sciences, Health and Life Sciences, Coleraine, UK BT52 1SA.
\end{abstract}

Corresponding author: Katie Trainor, University of Ulster Faculty of Life and Health Sciences, Health and Life Sciences, Coleraine, UK BT52 1SA. Email: trainork1@email.ulster.ac.uk.

\section{ABSTRACT}

Background: People with severe mental illness (PWSMI) die 15-20 years earlier than people in the general population and this is often due to preventable smoking-related health conditions. Studies that identify barriers and facilitators to smoking cessation are crucial for policy makers and health care professionals.

Aims: This appraisal aims to identify and critically appraise qualitative studies which explore smoking experiences and barriers to smoking cessation among PWSMI.

Method: Articles were retrieved from electronic health related databases including Web of Science, Scopus, PubMed, Sage, Biomed, Medline, Embase and electronic hand searches of bibliographies from key articles.

Results: Eleven papers were identified. Although the overall quality of studies were sufficient, most had limited information relating to trustworthiness and sociodemographic details. Cost savings and health benefits were frequently cited as facilitators to quitting, however may be of limited impact as smoking for existential purposes, social inclusion and mental health management appear to be considered highly important among PWSMI.

Conclusions: Findings were restricted to predominantly individual barriers to smoking cessation which may be more resistant to change as service users rely on smoking to manage their mental health and smoking is embedded in the culture of mental health settings.

Key words: Mental health disorders, cessation, tobacco control, qualitative research, public health

\section{Implications}

This critical appraisal identifies qualitative evidence regarding which factors facilitate or prevent individuals with severe mental illness from engaging with smoking cessation. Healthcare professionals and policy makers should address external barriers to quitting smoking as this may increase participation in intervention studies, inform policy and assist in the development of a feasible and acceptable smoking cessation intervention among 
PWSMI. Methodological considerations highlight that future research should include sociodemographic and contextual factors to improve utility and applicability of findings.

\section{INTRODUCTION}

\section{Background}

People with severe mental illness (PWSMI) die 15-20 years earlier than the general population and this is often due to preventable smoking-related health conditions rather than suicide [1-3]. Among PWSMI, smoking is associated with poor physical health outcomes, depressive symptoms, increased hospitalisations, poor treatment outcomes, reduced quality of life, stress and increased psychotic symptoms [4-7]. Smokers with SMI smoke more heavily, inhale more puffs and carbon monoxide per cigarette and are often highly dependent on nicotine compared to people in the general population. Therefore, they are a priority population for tobacco cessation efforts [8-10].

Motivation to quit among PWSMI is similar to general population samples [11]. However, 61$90 \%$ of people with schizophrenia smoke compared to $18-24 \%$ in the general population [1215]. Smoking prevalence in the general population has declined significantly over the past forty years [64, 65]. Reductions have been attributed to effective Public Health Agency (PHA) tobacco control strategies including media campaigns, increased taxation of cigarettes, smoking bans in public places, prescription of nicotine replacement therapy (NRT) and increased cessation support. However, in a national Australian survey, Cooper, et al. [60] highlighted that there was no decline in smoking prevalence rates among people with psychosis over 10 years. These findings are consistent with a meta-analysis of worldwide studies suggesting PWSMI are three times more likely to smoke than general population samples [64]. Observed reductions among general population samples have not been reflected in psychiatric populations, who experience more barriers to smoking cessation.

\section{Barriers and facilitators of smoking cessation}

Smoking cessation interventions are based on the transtheoretical model (TTM) which postulates that smokers' move from a stage of precontemplation to contemplation by formulating intentions to quit based on weighing up advantages and disadvantages of quitting $[16,17]$. However, it is uncertain if the TTM is applicable in guiding cessation among PWSMI [18, 61]. Further, health and lifestyle intervention studies are limited by small samples sizes and high attrition rates, with participation rates as low as $43 \%$, which are inadequately powered to assess statistical significance [19-21]. Medical research council [22] guidelines support phased intervention development to increase insight into 
mechanisms and theory which underpin behavioural change [19], therefore, barriers to quitting should be identified at both individual and external levels such as health provider and systemic levels [23].

Qualitative approaches are theory building rather than theory testing, allowing identification of barriers and facilitators of smoking cessation through exploration of smoking and quitting experiences and beliefs which may not have been predetermined by the researcher or treatment providers. Previous reviews have identified barriers to quitting smoking and participation in cessation trials [6, 24, 25]. However, there have been no reviews which critically appraise qualitative studies which identify barriers to smoking cessation; it is important that studies are methodologically sound and include contextual factors that affect local applicability to improve usefulness for policy makers and health care providers [26]. Furthermore, there is a paucity of research exploring external barriers and facilitators of cessation among PWSMI. Identifying external barriers to cessation may increase participation rates in intervention studies, inform policy and assist in the development of a feasible and acceptable smoking cessation intervention among PWSMI [27].

\section{Aims}

Given the discrepancy between PWSMI and general population smoking prevalence levels, it was deemed necessary for a comprehensive and critical appraisal of qualitative literature exploring smoking and quitting among PWSMI. This review will report barriers perceived by service users, family members and health care providers. Specifically, this review aims to (1) Critically appraise qualitative studies which identify barriers and facilitators of smoking cessation among PWSMI (2) explore reported barriers and facilitators of smoking cessation and (3) examine if qualitative studies identify systemic, treatment and health provider barriers and facilitators of smoking cessation.

\section{METHOD}

\section{Study design}

A narrative review method was utilised to integrate qualitative studies exploring barriers and facilitators to smoking cessation among PWSMI. A narrative review accommodated a comprehensive and flexible examination of the wide range of barriers and facilitators mentioned in the relevant literature. To appraise methodological quality, two contrasting frameworks were used simultaneously; ENTREQ [28] and Critical Appraisal Skills Programme [29]. Studies were not excluded on quality grounds as this review does not aim to exclude poor quality studies rather, critically appraise studies to enhance future research.

\section{Search methods}


A literature search was conducted using the following search terms: tobacco cessation, quitting, severe mental illness, schizophrenia, psychosis, bipolar, psychotic disorder, barriers, facilitators and qualitative (Figure one). Boolean combinations of these terms were searched in Web of Science, Scopus, PubMed, Sage, Biomed, Medline, Embase, Google Scholar and electronic hand searches in March 2015. Numerous terms were used to identify "people with severe mental illness" in order to distinguish SMI from common mental health disorders, such as anxiety or depression. For example, "schizophrenia" OR "severe mental illness" OR "bipolar disorder" OR "psychosis". Truncation symbols were used to replace the ending of "Qual*" to distinguish search results from quantitative studies. However, searching for 'qualitative' studies had limited utility as many papers were not appropriately identified as qualitative [30]. Therefore, papers were also identified from electronic hand searches of bibliographies of relevant articles, which had cited qualitative papers that had not appeared in initial search results.

\section{Inclusion and exclusion criteria}

Articles were reviewed if they met all of the following criteria: (a) they were published in the English language, (b) they were peer-reviewed studies with a qualitative component, published between 1980 and March 2015, (c) the research explored smoking and quitting experiences of people diagnosed with severe mental illness, and (d) studies identified barriers and facilitators of smoking cessation among PWSMI, perceived by service users, family members and/or health care providers. There were inconsistencies found in how SMI was defined in practice [31]. For the purposes of this review, severe mental illness is defined as a diagnosis of psychosis or personality disorder. Barriers were defined as reasons for smoking maintenance or reasons that prevented smoking cessation. Internal barriers were defined as individual and social factors which prevented cessation whereas external barriers were defined as systemic, health provider and treatment factors which prevented cessation. Facilitators were defined as reasons or factors that aided or improved chances of smoking cessation. There were no exclusion criteria for sample size. Intervention studies were only included if they were the mixed method study with a qualitative component exploring barriers and facilitators to quitting smoking.

\section{Data extraction}

Titles and abstracts were screened to identify which in the initial pool of papers made references to barriers and facilitators of smoking cessation. Articles meeting the criteria were then coded regarding barriers, facilitators, study setting, country where healthcare was located, study design, sample characteristics, recruitment, data saturation, data collection method, research methodology, reflexivity, trustworthiness: credibility, transferability, 
dependability and confirmability. The second researcher confirmed quality assessment screening.

\section{RESULTS}

\section{Search outcomes}

Four hundred and fifty-five studies were identified through the search strategy; 10 Web of Science; 188 Scopus; 133 PubMed; 72 Sage; 34 Biomed; 8 Medline; 10 Embase; 24 electronic hand searches and 19 from an explosion of references. Titles and abstracts were screened utilising inclusion and exclusion criteria. All relevant papers were retrieved. Duplicates were removed and study titles and abstracts which did not meet inclusion criteria were excluded. Eleven studies met inclusion criteria. The second author examined a random sample of identified articles to estimate interrater reliability. There was $100 \%$ agreement on inclusion and exclusion of studies.

[FIGURE 1.FLOW DIAGRAM OF REVIEW PROCESS HERE]

\section{Study characteristics}

Of the eleven studies included, six studies were based in the US [33, 35, 36, 42, 43, 38], two in Canada [40, 41], one study was based in Australia [34], one in New Zealand [37] and one in the UK [39]. All eleven studies reported study setting, inpatient/outpatient and number of participants. Five studies did not include participant characteristics including gender, age or diagnosis [33, 36, 37, 38, 42].

\section{[TABLE 1 HERE]}

\section{Quality assessment of studies}

The results of the quality assessment utilising CASP and ENTREQ are presented in Table 1. Recruitment descriptions and sampling procedures were reported in most studies. Three studies used a grounded theory design [33; 34; 35], one used a mixed method design [38], eight studies did not explicitly state study design. Three studies used grounded theory as an analysis technique [33-35], two used thematic analysis [36; 37], one study used content analysis as part of a mixed method study but did not state it was a mixed method study [41] and one study used a general inductive approach [39]. Five studies used semi-structured interviews [33; 34; 39; 40; 43], one used structured interviews as a component of a mixed study [41], and five studies used focus groups for data collection [35; 36; 37; 38; 42]. Only one study considered reflexivity [35]. Seven studies described the sample characteristics in 
detail, including age, gender and diagnosis [33; 34; 35; 39; 40; 41; 43]. Three studies stated that they reached data saturation [34;35;37]. Only five studies met all four components of trustworthiness [33; 34; 39; 40; 43].

\section{[TABLE 2 HERE]}

\section{Facilitators of smoking cessation}

Health and financial facilitators

All eleven studies identified facilitators of smoking cessation among PWSMI. The most commonly cited facilitators were health benefits [33; 35; 36; 39; 42; 43] and financial savings [33, 36; 39; 42; 43], however, these were often weighted as less important than perceived benefits of smoking (see Table 2).

\section{Tailored cessation support}

Other facilitators of cessation included flexible and tailored support offered at the optimum time [37; 39; 40]. Families of PWSMI stated it was important to have an accessible and responsive tobacco support service [37]. Lawn and colleagues [34] highlighted the importance of considering different diagnoses when tailoring smoking interventions as people with different diagnoses have different needs. One study suggested it was important to "feel ready to quit" [36]. It was highlighted that alternative ways to cope with stress and anxiety and increase self-efficacy and motivation should be offered to cope with the urge to smoke [39; 41]. Concerns about the deterioration of mental health after smoking cessation should be addressed and knowledge and skills surrounding smoking cessation should be taught [39].

\section{Health provider support}

Health providers were not cited as facilitators of quitting smoking except in one study [40]. It was suggested mental health service staff could facilitate smoking cessation by being more involved, committed and having consistent knowledge and training of Nicotine Replacement Therapy (NRT) and behavioural cessation techniques [37; 40].

\section{Social facilitators}

Social benefits such as no longer smelling of smoke and social approval for quitting were cited as facilitators in one study [36]. One study mentioned family advice as an important facilitator and another highlighted the importance of having family involvement and education for families around smoking cessation [33]. Peer modelling and changes in social norms were also important; smoking image became associated with risky and unpopular behaviour. 
Additionally, people smoked less in environments which were antipathetic to smoking [35; 38; 39].

\section{Individual barriers of smoking cessation}

Individual factors were the most commonly cited barriers to smoking cessation. These included the management of mental illness symptoms, social barriers and smoking for existential purposes.

\section{Smoking to manage mental health}

The most commonly cited individual barrier to cessation was smoking to reduce or cope with illness-related factors, including; managing mental health symptoms, side effects and preventing relapse, which was often perceived as more important than physical health [33, $39,42,34 ; 39 ; 41]$. It was commonly reported that smoking improved illness related factors such as; attentional, cognitive, motivational, problem solving and negative symptoms [34; 36 ; $41 ; 43$ ]. Low self-efficacy was cited as a barrier to cessation in four studies [35; 38; 39; 40]. Smoking had a role in reducing negative affect; relieving grief, anger, anxiety, depression, irritability, sadness and nervousness [35; 43; 36; 38; 39; 41; 39]. It was also an important coping resource in dealing with stress [33; 39; 42].

\section{Existential role of smoking}

Smoking was perceived as playing an existential role in the lives of PWSMI [34], as smoking played an intrinsic role in their everyday routines, lifestyles and identities. Smoking helped people compartmentalise their time, was their main source of activity and helped reduce boredom [43; 36; 38; 37]. It was often described as their "only pleasure" [36; 37; 38]. Smoking was also perceived as a method of control [34, 35].

\section{Social barriers}

Smoking was perceived as a way to fit in, cope with exclusion, "be part of something", offering relief from loneliness and alleviated stigma [33; 34; 35; 38; 36; 40; 42]. Social influence and smoking peers facilitated a wide acceptance of smoking [34; 38; 39; 40; 42]. Lack of cessation encouragement from significant others was also cited as a common barrier [39; 42; 43].

\section{Health provider barriers}

Five studies highlighted healthcare provider barriers [34;35; 37; 39; 42]; suggesting there was perceived lack of encouragement to quit by any health providers. Psychiatrists who discussed quitting approached it with judgmental connotations which impacted on self- 
esteem [34; 35; 39]. It was cited that lack of support from healthcare providers, staff smoking with patients, using cigarettes as rewards, lack of knowledge about cessation and lack of responsibility for smoking cessation were perceived barriers to smoking cessation [35; 39; $37 ; 42]$.

\section{Systemic barriers}

Five studies identified systemic barriers to smoking cessation [37; 34; 35; 39; 43]. One study mentioned government policy, messages and PHA policy as a facilitator of smoking cessation [33]. One study noted a lack of consistency in smoke-free practice and alternative activities [37]. One study mentioned that a lack of practice guidelines, lack of staff training, lack of resources to achieve smoke-free policy and no targets to reduce smoking as barriers to smoking cessation among PWSMI [39].

\section{Treatment barriers}

Five studies mentioned pharmacotherapies and the issues surrounding these regarding barriers and facilitators to smoking cessation [35; 37; 36; 42; 43]. Staff concerns about harmful effects and expense of NRT, inconsistent information about NRT given by staff and availability and access to NRT were cited as barriers to smoking cessation [35; 36; 37; 42].

\section{DISCUSSION}

This critical appraisal aimed to identify and critically appraise qualitative studies which explore smoking experiences and barriers to quitting smoking among PWSMI. Findings highlight methodological shortcomings; few studies met all four components of trustworthiness or reported sociodemographic details. Secondly, this review aimed to identify external barriers to smoking cessation, including; systemic, health provider and treatment barriers and facilitators which have been associated with declines in smoking prevalence levels in the general population. Findings demonstrate that qualitative studies focused predominantly on individual barriers rather than external barriers to cessation.

\section{Methodological robustness}

While the overall quality of studies was sufficient, most did not provide information relating to trustworthiness; half of the studies did not describe the sample characteristics, including age, gender or diagnosis which reduces transferability of findings. Different mental illnesses may be associated with different barriers and facilitators due to heterogeneity between symptoms, medication effects and stigma; all of which were expressed as reasons for smoking [34]. This limits the extent to which findings can be generalised, particularly as 
health beliefs vary among different age groups and vulnerability to health risk and response to intervention is associated with clinical severity and age $[44 ; 45]$.

Individual related barriers and facilitators to cessation

Smoking was reported by participants as important for managing symptoms and facilitated social inclusion. Smoking was perceived as having an existential role for PWSMI; it was engrained in their everyday existence and gave them something to do. These barriers extend those which are typically reported by the general population; addiction, habit, stress, weight gain and enjoyment [46; 47]. Health problems and cost savings were frequently cited facilitators of quitting, however, despite awareness of the health risks, PWSMI continued to smoke, and health and financial costs of smoking did not facilitate cessation [33; 35; 36; 39; 43]. This is consistent with previous findings which show tax increases on cigarettes do not reduce smoking among PWSMI [48]. Unlike theories of health behaviour change which posit that knowledge of risk, risk assessment and decisional balance determine individual action to change behaviour, quitters did not appear to weigh up pros and cons of smoking; spontaneous quitting was triggered by feelings of disgust or serious breathing problems. This is consistent with recent findings suggesting that prior planning may not precede quitting [61]. The TTM has been criticised for not acknowledging different interpretations of risk, and may not be applicable among PWSMI [18; 49; 62]; suggesting current cessation models and guidelines may hinder quitting [33; 43].

\section{Systemic facilitators and barriers of smoking cessation}

Decline in smoking among the general population has been attributed to effective Public Health Agency (PHA) strategies. Only one study in this review mentioned government strategy regarding facilitating quitting smoking [33]. Findings suggest that more guidelines and training for staff, resources to achieve smoke-free policy and targets on reducing smoking are required to increase smoking cessation in this population [34; 35; $3743 ; 39$ ]. However, over half of studies identified did not explore systemic or health provider barriers to cessation. This suggests that systemic and health provider factors are rarely barriers to cessation or, more likely; PWSMI are unaware of the responsibility of health services in providing cessation support, therefore, did not spontaneously suggest they were barriers to smoking cessation. Bronfenbrenner's [50, 63] ecological framework suggests that to implement a feasible intervention it is important to identify barriers at all levels. Particularly as PWSMI may find it more difficult to quit due to symptoms of mental illness, therefore, may depend on health providers and systemic facilitators to achieve and maintain cessation.

Health provider facilitators and barriers to cessation 
Previous findings suggest that if quit attempts are spontaneous and unplanned, health providers may need to provide more smoking cessation support during the action phase, rather than precontemplation stage, as postulated by the transtheoretical model [61]. However, health professionals were mentioned as a facilitator of cessation in only one study [40]. Five studies identified health provider barriers to quitting. These barriers are troubling as providers' attitudes towards NRT and cessation may hinder quitting and if support was provided; it was perceived by PWSMI as judgmental. This consequently lowered their selfesteem and increased their sense of powerlessness [34; 35; 39; 43]. Findings are consistent with literature emphasising health disparities are due to a care gap not being effectively met by primary care or secondary mental health services [51; 52]. Current findings highlight that health providers are not perceived as sources of smoking cessation support; contrasting with PHA policy and findings which suggest general practice had the highest number of people setting quit dates GPs should ask about smoking, offer quitting advice and prescribe NRT $[14 ; 53-56]$.

\section{Pharmacotherapy treatment barriers and facilitators of cessation}

Despite research suggesting that PWSMI do not use effective cessation treatments and that pharmacotherapies have been shown to be effective in psychiatric populations [56,57]; only $50 \%$ of studies explored barriers and facilitators surrounding attitudes and beliefs towards NRT. This is problematic as NRT is a key component of cessation interventions. In the UK $91 \%$ of people in the general population who quit using NHS services received pharmacotherapy [53]. Therefore, it is crucial to explore barriers surrounding NRT in qualitative studies to improve cessation success among PWSMI. It may be the case that PWSMI were unaware of the availability of pharmacotherapies, therefore, did not mention it as a barrier or facilitator of cessation during interviews. Alternatively, studies may have taken place when access to NRT was not as widely available in the community. Findings suggest that participants expressed negative views about NRT effectiveness and safety and received inconsistent information from staff $[35 ; 37 ; 38 ; 43]$. US and New Zealand studies mentioned the cost of NRT as a barrier, juxtaposed to UK and Canadian studies where NRT is funded by national health services.

\section{Strengths and limitations}

The review process was restricted to English language journals only and peer review publications, therefore, we may have missed some studies that were published within the grey literature. Searching for 'qualitative' studies was unhelpful as the MeSH heading 'Qualitative Research' was introduced in 2003 and after this many papers had varied use of the term 'qualitative' [30], therefore, important studies may not have been identified. 
Cochrane review guidelines emphasise that reviews should not be limited to well-known databases as this may result in missing useful information. Therefore, electronic hand searches of bibliographies from key articles were used to expand search results.

Reliability of conclusions may be enhanced if demographics and external barriers to cessation were reported across studies, however, it was not the scope of this review to exclude studies on this premise but to critically appraise findings to enhance usefulness for future research and cessation interventions. Furthermore, no weight was given to barriers and facilitators. Although participants may have suggested more facilitators than barriers to smoking cessation, barriers were often weighted more; for example, managing mental health symptomology by continuing to smoke was perceived as a greater concern than future health benefits of quitting smoking. Therefore, it was difficult to conclude which facilitators would realistically increase cessation success. However, recording commonly cited barriers and facilitators allowed the authors to explore different meanings PWSMI assigned to health risk associated with smoking, which is important to consider in changing health behaviours [50] and understanding the utility of health behaviour models.

\section{Implications}

Smoking cessation strategies should aim to address negative and inaccurate views of NRT, reduce individual barriers to smoking cessation through finding alternative strategies for achieving cognitive, emotive, symptoms and stress relief benefits and develop better ways to tackle and infiltrate pro-smoking cultures such as peer modelling. Flexible and tailored support, given at the right time, was perceived as a key component of smoking cessation; consistent with previous reviews findings that service users' personal perspectives are vital in changing health behaviours [25; 58]. Further, taking advantage of quit opportunities rather than weighing pros and cons and planning quit dates [61;62], as postulated by TTM theory, may increase the efficacy of smoking cessation interventions.

Future studies should report age, gender, smoking status and diagnosis to enhance trustworthiness. Most studies did not explicitly explore external barriers to smoking cessation, suggesting that further research is required to understand issues surrounding smoking cessation beyond individual related factors. Although barriers and facilitators were self-reported, systemic barriers, especially those related to health providers, may also be significant. Future research should explore systemic issues further to understand external barriers of smoking cessation and facilitate tailored intervention implementation for PWSMI. Particularly as PHA strategies have been successful in reducing smoking prevalence levels in the general population [15]. 


\section{Conclusion}

This critical appraisal provides an insight into methodological challenges of understanding the barriers and facilitators of smoking cessation among PWSMI. Findings are restricted to mainly individual barriers, which may be less resistant to change as service users rely on smoking to manage their mental health and live in pro-smoking cultures. Additional qualitative work is required as smoking cessation needs to be addressed at all levels. This includes enacting measures at systemic, health provider and service user individual levels $[50,63]$ to understand and mitigate alarmingly high smoking prevalence levels among this vulnerable population.

\section{Funding}

Study funded by Department of Education and Learning, Northern Ireland.

\section{Declaration of Interests}

No competing interests.

\section{REFERENCES}

1. Saha S, Chant D, McGrath J. A systematic review of mortality in schizophrenia: Is the differential mortality gap worsening over time? Arch Gen Psychiatry. 2007;64:11231131. doi:10.1001/archpsyc.64.10.1123.

2. Parks J, Svendsen D, Singer P. Morbidity and mortality in people with serious mental illness. . National Association of State Mental Health Program Directors (NASMHPD) Medical Directors Council. 2006. Available at www.nasmhpd.org/publications/technical reports accessed 2/2/15.

3. Colton, C. W. and Manderscheid, R. W. (2006). Congruencies in Increased Mortality Rates, Years of Potential Life Lost, and Causes of Death Among Public Mental Health Clients in Eight States. Preventing chronic disease,. 2006;3. Available at http://www.ncbi.nlm.nih.gov/pmc/articles/PMC1563985/ accessed 16/01/16.

4. Williams JM, Ziedonis D. Addressing tobacco among individuals with a mental illness or an addiction. Addictive behaviours, 2004;29(6):1067-1083.

doi:10.1016/j.addbeh.2004.03.009

5. Kelly C, McCreadie RG. Smoking habits, current symptoms, and premorbid characteristics of schizophrenic patients in Nithsdale, Scotland. Am J Psychiatry. 
1999;156:1751-1757. Available at

http://ajp.psychiatryonline.org/doi/abs/10.1176/ajp.156.11.1751. Accessed 11/7/15.

6. Morris CD, Waxmonsky JA, May MG, Tinkelman DG, Dickinson M, Giese AA. Smoking reduction for persons with mental illnesses: 6-Month results from community-based interventions. Community Ment Health J. 2011;47:694-702. doi: 10.1007/s10597-0119411-z

7. Dixon L, Medoff DR, Wohlheiter K, et al. Correlates of severity of smoking among persons with severe mental illness. Am J Addict. 2007;16(2):101-110. doi:10.1080/10550490601184415

8. Tidey JW, Rohsenow DJ, Kaplan GB, Swift RM. Cigarette smoking topography in smokers with schizophrenia and matched non-psychiatric controls. Drug Alcohol Depend. 2005;80:259-265. doi:10.1016/j.drugalcdep.2005.04.002

9. Williams JM, Gandhi KK, Steinberg ML, Foulds J, Ziedonis DM, Benowitz NL. Higher nicotine and carbon monoxide levels in menthol cigarette smokers with and without schizophrenia. Nicotine Tob Res. 2007;9:873-881. doi: 10.1080/14622200701484995

10. Zhang M, Zhao Z, He L, Wan C. A meta-analysis of oxidative stress markers in schizophrenia. Sci China Life Sci. 2010;53:112-124. doi: 10.1007/s11427-010-0013-8.

11. Siru R, Hulse GK, Tait RJ. Assessing motivation to quit smoking in people with mental illness. Addiction. 2009;104:719-733. doi: 10.1111/j.1360-0443.2009.02545.x

12. Wade D, Harrigan S, Edwards J, Burgess PM, Whelan G, McGorry PD. Patterns and predictors of substance use disorders and daily tobacco use in first-episode psychosis. Aust N Z J Psychiatry. 2005;39:892-898. doi:10.1080/j.1440-1614.2005.01699.x

13. Ziedonis D, Hitsman B, Beckham JC, et al. Tobacco use and cessation in psychiatric disorders: National Institute of Mental Health report. Nicotine Tobacco Res. 2008;10:1691-1715. doi: 10.1080/14622200802443569

14. O'Connor RJ, Giovino GA, Kozlowski LT, et al. Changes in nicotine intake and cigarette use over time in two nationally representative cross-sectional samples of smokers. Am J Epidemiol. 2006;164:750-759. doi: 10.1093/aje/kwj263

15. Annual Report of the Chief Medical Officer 2013, Public Mental Health Priorities: Investing in the Evidence. 
16. DiClemente CC, Prochaska JO. Self-change and therapy change of smoking behavior: A comparison of processes of change in cessation and maintenance. Addict Behav. 1982;7:133-142. doi:10.1016/0306-4603(82)90038-7

17. Prochaska JO, Velicer WF, Rossi JS, et al. Stages of change and decisional balance for 12 problem behaviors. Health Psychology. 1994;13:39-46. doi.org/10.1037/02786133.13.1.39

18. Dixon LB, Medoff D, Goldberg R, et al. Is implementation of the 5 A's of smoking cessation at community mental health centers effective for reduction of smoking by patients with serious mental illness? American Journal on Addictions. 2009;18(5):386392. doi: $10.3109 / 10550490903077747$

19. McNamee L, Mead G, MacGillivray S, Lawrie SM. Schizophrenia, poor physical health and physical activity: evidence-based interventions are required to reduce major health inequalities. British Journal of Psychiatry. 2013;203:239-241. doi: 10.1192/bjp.bp.112.125070

20. Druss BG, Zhao L, von Esenwein SA, et al. The Health and Recovery Peer (HARP) Program: A peer-led intervention to improve medical self-management for persons with serious mental illness. Schizophr Res. 2010;118:264-270. doi:10.1016/j.schres.2010.01.026.

21. Morris, C. D., Waxmonsky, J. A., May, et al. (2009). What do persons with mental illnesses need to quit smoking? Mental health consumer and provider perspectives. Psychiatric rehabilitation journal, 32(4), 276. doi: 10.2975/32.4.2009.276.284

22. Craig P, Dieppe P, Macintyre S, Michie S, Nazareth I, Petticrew M. Developing and evaluating complex interventions: the new Medical Research Council guidance. $\mathrm{Br} \mathrm{Med}$ J. 2008;337:a1655. doi: 10.1136/bmj.a1655

23. Datta J, Petticrew M. Challenges to evaluating complex interventions: a content analysis of published papers. BMC Public Health. 2013;13:568. doi: 10.1186/14712458-13-568

24. Baker A, Richmond $R$, Haile $M$, et al. Characteristics of smokers with a psychotic disorder and implications for smoking interventions. Psychiatry Res. 2007;150:141-152. doi:10.1016/j.psychres.2006.05.021

25. Roberts SH, Bailey JE. An ethnographic study of the incentives and barriers to lifestyle interventions for people with severe mental illness. J Adv Nurs. 2013;69:2514-2524. 
Available at http://onlinelibrary.wiley.com/doi/10.1111/j.1365-2648.2010.05546.x/pdf accessd 1/7/15.

26. Noyes, J., Popay, J., Pearson, A., Hannes, K., \& Booth, A. Qualitative research and cochrane reviews. In cochrane handbook for systematic reviews of interventions: Cochrane book series . In: Cochrane Handbook for Systematic Reviews of Interventions: Cochrane Book Series . ; 2008:571-591. Available at https://www.researchgate.net/profile/Elizabeth Waters/publication/228028274 Reviews in Public Health and Health Promotion/links/02bfe50d0bb5dd3888000000.pdf\#pag $\underline{\mathrm{e}=595}$ accessed $1 / 8 / 15$.

27. Lavis J, Davies H, Oxman A, Denis J, Golden-Biddle K, Ferlie E. Towards systematic reviews that inform health care management and policy-making. J Health Serv Res Policy. 2005;10 Suppl 1:35-48. doi: 10.1258/1355819054308549

28. Tong A, Flemming K, Mclnnes E, Oliver S, Craig J. Enhancing transparency in reporting the synthesis of qualitative research: ENTREQ. Bmc Medical Research Methodology. 2012;12:181. doi: 10.1186/1471-2288-12-181.

29. CASP P. Critical appraisal skills programme. ten questions to help you make sense of qualitative research.1999.

30. Grant MJ. How does your searching grow? A survey of search preferences and the use of optimal search strategies in the identification of qualitative research. Health information and libraries journal. 2004;21:21-32. doi: 10.1111/j.14711842.2004.00483.x

31. Slade M, Powell R, Strathdee G. Current approaches to identifying the severely mentally ill. Soc Psychiatry Psychiatr Epidemiol. 1997;32:177-184. doi 10.1007/BF00788236

32. National Institute of Mental Health. Towards a Model for a Comprehensive CommunityBased Mental Health System. Washington, DC: NIMH.:1987 Accessed 19/08/15.

33. Davis, K., Brunette, M., Vorhies, V., Ferron, J., \& Whitley, R. A qualitative study of how individuals with severe mental illness assess smoking risks. . Mental Health and Substance Use: Dual Diagnosis. 2010;3:110-123. doi:10.1080/17523281003738745

34. Lawn SJ, Pols RG, Barber JG. Smoking and quitting: a qualitative study with community-living psychiatric clients. Soc Sci Med. 2002;54:93-104. doi:10.1016/S02779536(01)00008-9 
35. Solway ES. The lived experiences of tobacco use, dependence, and cessation: Insights and perspectives of people with mental illness. Health Soc Work. 2011;36:19-32. doi: $10.1093 / \mathrm{hsw} / 36.1 .19$

36. Lucksted A, Dixon LB, Sembly JB. A focus group pilot study of tobacco smoking among psychosocial rehabilitation clients. Psychiatric Services. 2000;51:1544-1548. doi.org/10.1176/appi.ps.51.12.1544

37. Missen RL, Brannelly T, Newton-Howes G. Qualitative exploration of family perspectives of smoke-free mental health and addiction services. International Journal of Mental Health Nursing. 2013;22:294-303. doi:10.1111/j.1447-0349.2012.00882.x

38. Snyder, M., McDevitt, J., \& Painter, S. (2008). Smoking cessation and serious mental illness. Archives of psychiatric nursing, 22(5), 297-304. Snyder M, McDevitt J, Painter S. Smoking Cessation and Serious Mental Illness. Arch Psychiatr Nurs. 2008;22:297304. doi:10.1016/j.apnu.2007.08.007

39. Kerr S, Woods C, Knussen C, Watson H, Hunter R. Breaking the habit: a qualitative exploration of barriers and facilitators to smoking cessation in people with enduring mental health problems. BMC Public Health. 2013;13:221. doi: 10.1186/1471-2458-13221

40. Rae J, Pettey D, Aubry T, Stol J. Factors affecting smoking cessation efforts of people with severe mental illness: A qualitative study. J Dual Diagn. 2015;11:42-49. doi:10.1080/15504263.2014.992096

41. Forchuk C, Norman R, Malla A, et al. Schizophrenia and the motivation for smoking. Perspect Psychiatr Care. 2002;38:41-49. doi: 10.1111/j.1744-6163.2002.tb00656.x

42. Nawaz S, Frounfelker R, Ferron JC, Carpenter-Song EA, Davis K, Brunette MF. Smoking and quitting beliefs, attitudes, and behaviors among smokers with severe mental illness from three race/ethnicity groups. J Dual Diagn. 2012;8:180-187. doi: 10.1080/15504263.2012.697449.

43. Esterberg ML, Compton MT. Smoking behavior in persons with a schizophreniaspectrum disorder: a qualitative investigation of the transtheoretical model. Soc Sci Med. 2005;61:293-303. doi:10.1016/j.socscimed.2004.11.057

44. Ferron JC, Brunette MF, He X, Xie H, McHugo GJ, Drake RE. Course of Smoking and Quit Attempts Among Clients With Co-occurring Severe Mental Illness and Substance Use Disorders. Psychiatric Services. 2011;62:353-359. doi: 10.1176/appi.ps.62.4.353

45. Norcross JC, Krebs PM, Prochaska JO. Stages of change. J Clin Psychol. 2011;67:143-154. doi: 10.1002/jclp.20758 
46. Guirguis AB, Ray SM, Zingone MM, Airee A, Franks AS, Keenum AJ. Smoking cessation: barriers to success and readiness to change. Tennessee medicine : journal of the Tennessee Medical Association. 2010;103:45-9.Available at http://europepmc.org/abstract/med/21138107 accessed 1/9/15

47. Fidler JA, West R. Self-perceived smoking motives and their correlates in a general population sample. Nicotine Tob Res. 2009;11:1182-1188. doi: 10.1093/ntr/ntp120

48. Ashton M, Rigby A, Galletly C. Do population-wide tobacco control approaches help smokers with mental illness? Aust New Zealand J Psychiatry. 2014;48:121-123. doi:10.1177/0004867413502093

49. Addington J, El-Guebaly N, Duchak V, Hodgins D. Using measures of readiness to change in individuals with schizophrenia. Am J Drug Alcohol Abuse. 1999;25:151-161. doi:10.1081/ADA-100101851

50. Bronfenbrenner, U.The Ecology of Human Development: Experiments by Design and Nature. ; 1979.

51. Happell B, Scott D, Platania-Phung C, Nankivell J. Should we or shouldn't we? Mental health nurses' views on physical health care of mental health consumers. Int $J$ Ment Health Nurs. 2012;21:202-210. doi: 10.1111/j.1447-0349.2011.00799.x

52. De Hert M, Correll CU, Bobes J, et al. Physical illness in patients with severe mental disorders. I. Prevalence, impact of medications and disparities in health care. World Psychiatry. 2011;10:52-77.doi: 10.1002/j.2051-5545.2011.tb00014.x

53. Statistics on NHS Stop Smoking Services in England April 2014 to March 2015 Final report. 2015.

54. Nicotine management policy. 2015. Available at http://www.candi.nhs.uk/sites/default/files/Documents/Policies/Nicotine\%20Managemen t\%20Policy\%20CL20 July\%202015.pdf Accessed 3/9, 2015

55. Annual Report of the Chief Medical Officer. Public Mental Health Priorities: Investing in the Evidence. Available at:

https://www.gov.uk/government/uploads/system/uploads/attachment data/file/413196/ CMO web doc.pdf. Accessed 2/2, 2015.

56. NHS England (2014) NHS England pledge to help patients with serious mental illness Available at: www.england.nhs.uk/2014/01/20/mental-illness/ accessed on 11/2/15 
57. Banham L, Gilbody S. Smoking cessation in severe mental illness: What works? Addiction. 2010;105:1176-1189. doi: 10.1111/j.1360-0443.2010.02946.x

58. Tsoi DT, Porwal M, Webster AC. Interventions for smoking cessation and reduction in individuals with schizophrenia. Cochrane Database Syst Rev. 2013;2. doi: 10.1002/14651858.CD007253.pub3

59. Barnes M, Davis A, Rogers H. Women's voices, Women's choices: Experiences and creativity in consulting women users of mental health services. J Ment Health. 2006;15:329-341. doi:10.1080/09638230600700664

60. Cooper J, Mancuso SG, Borland R, Slade T, Galletly C, Castle D. Tobacco smoking among people living with a psychotic illness: The second australian survey of psychosis. Aust New Zealand J Psychiatry. 2012;46(9):851-863.

61. Moeller-Saxone K, Segan C. The role of planning in naturalistic quitting success among people with severe mental illness. Int J Ment Health Addict. 2015:1-13. doi: 10.1007/s11469-015-9609-3

62. West R. Time for a change: Putting the transtheoretical (stages of change) model to rest. Addiction. 2005;100(8):1036-1039.

63. Lawn SJ. Systemic barriers to quitting smoking among institutionalised mental health service populations: A comparison of two australian sites. Int J Soc Psychiatry. 2004;50(3):204-215.

64. de Leon J, Diaz FJ. A meta-analysis of worldwide studies demonstrates an association between schizophrenia and tobacco smoking behaviors. Schizophr Res. 2005;76(23):135-157.

65. Lawlor DA, Frankel S, Shaw M, Ebrahim S, Smith GD. Smoking and ill health: Does lay epidemiology explain the failure of smoking cessation programs among deprived populations? Am J Public Health. 2003;93(2):266-270.

66. Rink M, Shariat SF. Re: Global effects of smoking, of quitting, and of taxing tobacco. Eur Urol. 2014;66(1):176-178. 
Table 1. Methodological Robustness: CASP $^{*}$ criteria of qualitative studies $(n=11)$

\begin{tabular}{|c|c|c|c|c|c|c|c|c|c|c|c|c|}
\hline Study & $\begin{array}{l}\text { Approp } \\
\text { riate } \\
\text { Study } \\
\text { design? }\end{array}$ & $\begin{array}{l}\text { Setting } \\
\text { descri } \\
\text { ption }\end{array}$ & $\begin{array}{l}\text { Sample } \\
\text { characte } \\
\text { ristics }\end{array}$ & $\begin{array}{l}\text { Recr } \\
\text { uit- } \\
\text { men } \\
t\end{array}$ & $\begin{array}{l}\text { Data } \\
\text { satura } \\
\text { tion }\end{array}$ & $\begin{array}{l}\text { Data } \\
\text { collectio } \\
\text { n } \\
\text { method }\end{array}$ & $\begin{array}{l}\text { Analysis } \\
\text { techniq } \\
\text { ue }\end{array}$ & $\begin{array}{l}\text { Reflex } \\
\text { ivity }\end{array}$ & $\begin{array}{l}\text { Cred } \\
\text { (inte } \\
\text { rnal } \\
\text { validi } \\
\text { ty) }\end{array}$ & $\begin{array}{l}\text { Transfe } \\
\text { rable }\end{array}$ & $\begin{array}{l}\text { Depen } \\
\text { dable } \\
\text { (reliabil } \\
\text { ity) }\end{array}$ & $\begin{array}{l}\text { Confirm } \\
\text { ability }\end{array}$ \\
\hline $\begin{array}{l}\text { Davis } \\
\text { et } \\
\text { al.[33] }\end{array}$ & Yes & Yes & Yes & Yes & No & $\begin{array}{l}\text { Semi } \\
\text { structure } \\
d \\
\text { intervie } \\
\text { ws }\end{array}$ & $\begin{array}{l}\text { Ground } \\
\text { ed } \\
\text { theory }\end{array}$ & No & Yes & Yes & Yes & Yes \\
\hline $\begin{array}{l}\text { Lawn } \\
\& \text { pols } \\
{[34]}\end{array}$ & Yes & Yes & Yes & Yes & Yes & $\begin{array}{l}\text { Semi } \\
\text { structure } \\
\text { d } \\
\text { intervie } \\
\text { ws }\end{array}$ & $\begin{array}{l}\text { Ground } \\
\text { ed } \\
\text { theory }\end{array}$ & No & Yes & Yes & Yes & Yes \\
\hline $\begin{array}{l}\text { Solwa } \\
y \text {, et } \\
\text { al [35] }\end{array}$ & Yes & Yes & Yes & No & Yes & $\begin{array}{l}\text { Focus } \\
\text { group }\end{array}$ & $\begin{array}{l}\text { Ground } \\
\text { ed } \\
\text { theory }\end{array}$ & Yes & Yes & Yes & Yes & No \\
\hline $\begin{array}{l}\text { Luckst } \\
\text { ed, et } \\
\text { al [36] }\end{array}$ & Yes & Yes & No & Yes & No & $\begin{array}{l}5 \text { Focus } \\
\text { groups }\end{array}$ & $\begin{array}{l}\text { Themati } \\
\text { c } \\
\text { analysis }\end{array}$ & No & Yes & No & Yes & Yes \\
\hline $\begin{array}{l}\text { Misse } \\
\mathrm{n} \text {, et } \\
\text { al [37] }\end{array}$ & Yes & Yes & No & Yes & Yes & $\begin{array}{l}2 \text { Focus } \\
\text { group }\end{array}$ & $\begin{array}{l}\text { Themati } \\
\text { c } \\
\text { analysis }\end{array}$ & No & Yes & No & Yes & Yes \\
\hline $\begin{array}{l}\text { Snyde } \\
r \text {, et al } \\
{[38]}\end{array}$ & $\begin{array}{l}\text { None } \\
\text { stated }\end{array}$ & Yes & No & Yes & No & $\begin{array}{l}\text { Focus } \\
\text { groups }\end{array}$ & $\begin{array}{l}\text { None } \\
\text { stated }\end{array}$ & No & Yes & No & No & Yes \\
\hline $\begin{array}{l}\text { Kerr, } \\
\text { et al } \\
{[39]}\end{array}$ & Yes & Yes & Yes & Yes & No & $\begin{array}{l}\text { Semi } \\
\text { structure } \\
d \\
\text { intervie } \\
\text { ws }\end{array}$ & $\begin{array}{l}\text { Framew } \\
\text { ork } \\
\text { analysis }\end{array}$ & No & Yes & Yes & Yes & Yes \\
\hline $\begin{array}{l}\text { Rae, } \\
\text { et al } \\
{[40]}\end{array}$ & Yes & Yes & Yes & Yes & No & $\begin{array}{l}\text { Semi } \\
\text { structure } \\
\text { d } \\
\text { intervie } \\
\text { w }\end{array}$ & $\begin{array}{l}\text { General } \\
\text { inductiv } \\
\mathrm{e} \\
\text { approac } \\
\mathrm{h}\end{array}$ & No & Yes & Yes & Yes & Yes \\
\hline $\begin{array}{l}\text { Forch } \\
\text { uck, } \\
\text { et } \\
\text { al[41] }\end{array}$ & Yes & Yes & Yes & Yes & No & $\begin{array}{l}\text { Structur } \\
\text { ed } \\
\text { intervie } \\
\text { w (after } \\
\text { question } \\
\text { naire) }\end{array}$ & $\begin{array}{l}\text { Content } \\
\text { analysis }\end{array}$ & No & Yes & No & Yes & No \\
\hline $\begin{array}{l}\text { Nawa } \\
z \text {, et al } \\
{[42]}\end{array}$ & $\begin{array}{l}\text { None } \\
\text { stated }\end{array}$ & Yes & No & Yes & No & $\begin{array}{l}6 \text { Focus } \\
\text { groups }\end{array}$ & $\begin{array}{l}\text { None } \\
\text { stated }\end{array}$ & No & Yes & No & Yes & Yes \\
\hline $\begin{array}{l}\text { Esterb } \\
\text { erg, et } \\
\text { al [43] }\end{array}$ & Yes & Yes & Yes & Yes & No & $\begin{array}{l}\text { Semi } \\
\text { structure } \\
\text { d } \\
\text { intervie } \\
\text { w }\end{array}$ & $\begin{array}{l}\text { Traditio } \\
\text { nal } \\
\text { themati } \\
\text { c } \\
\text { method } \\
\text { ology }\end{array}$ & No & Yes & Yes & Yes & Yes \\
\hline
\end{tabular}

*CASP: Critical Appraisal Skills Program (2006) 
Table 2. Barriers and facilitators of smoking cessation among PWSMI

\begin{tabular}{|c|c|c|c|c|c|c|c|}
\hline Study & Setting & Facilitators & $\begin{array}{l}\text { Individual } \\
\text { Barriers }\end{array}$ & $\begin{array}{l}\text { Social } \\
\text { Barriers? }\end{array}$ & $\begin{array}{l}\text { Health } \\
\text { Provider } \\
\text { barriers? }\end{array}$ & $\begin{array}{l}\text { NRT } \\
\text { Discussed? }\end{array}$ & $\begin{array}{l}\text { Systemic } \\
\text { barriers } \\
\text { mentioned? }\end{array}$ \\
\hline $\begin{array}{l}\text { Davis et } \\
\text { al., } \\
\text { [33] }\end{array}$ & $\begin{array}{l}31 \text { PWSMI: } \\
\text { smokers, } \\
\text { previous } \\
\text { smokers and } \\
\text { non-smokers. } \\
\text { Illinois, USA }\end{array}$ & $\begin{array}{l}\text { Financial reasons, } \\
\text { disgust, societal } \\
\text { messages of risk, } \\
\text { family and medical } \\
\text { advice, government } \\
\text { policy and smoking } \\
\text { related health } \\
\text { problem }\end{array}$ & $\begin{array}{l}\text { Managing mental } \\
\text { health, social } \\
\text { benefits, beliefs of } \\
\text { invulnerability, down } \\
\text { played smoking } \\
\text { related health } \\
\text { problems }\end{array}$ & $\begin{array}{l}\text { Social } \\
\text { benefits of } \\
\text { smoking. }\end{array}$ & None & No & No \\
\hline $\begin{array}{l}\text { Lawn \& } \\
\text { pols [34] }\end{array}$ & $\begin{array}{l}\text { Patients with } \\
\text { schizophrenia, } \\
\text { bi-polar } \\
\text { affective } \\
\text { disorder, } \\
\text { depression, and } \\
\text { personality } \\
\text { disorder were } \\
\text { studied ( } n=24) \text {, } \\
\text { South Australia }\end{array}$ & $\begin{array}{l}\text { Recognising people } \\
\text { with different } \\
\text { diagnoses have } \\
\text { different needs }\end{array}$ & $\begin{array}{l}\text { Existential role: } \\
\text { reducing stigma, } \\
\text { promoting freedoms } \\
\text { Managing mental } \\
\text { health, symbol of } \\
\text { control, Smoking for } \\
\text { identity }\end{array}$ & $\begin{array}{l}\text { Reinforcem } \\
\text { ent and } \\
\text { acceptance } \\
\text { of smoking. }\end{array}$ & $\begin{array}{l}\text { Psychiatrist } \\
\text { rarely } \\
\text { mentioned } \\
\text { their smoking }\end{array}$ & Yes & $\begin{array}{l}\text { Doctors were } \\
\text { demarcating the } \\
\text { area of their } \\
\text { responsibility for } \\
\text { treatment and } \\
\text { smoking cessation } \\
\text { was not included } \\
\text { in that area. }\end{array}$ \\
\hline $\begin{array}{l}\text { Solway, } \\
\text { et al } \\
\text { [35] }\end{array}$ & $\begin{array}{l}4 \text { groups: } 2 \\
\text { smokers, never } \\
\text { smoker and } \\
\text { previous smoker } \\
\text { from outpatient } \\
\text { mental health } \\
\text { services. } \\
\text { California, USA, }\end{array}$ & $\begin{array}{l}\text { Health concerns, } \\
\text { changes in norms } \\
\text { and values, image of } \\
\text { smoking as risky and } \\
\text { unpopular } \\
\text { behaviour, which } \\
\text { transformed it into a } \\
\text { barrier to } \\
\text { socialisation. }\end{array}$ & $\begin{array}{l}\text { Coping mechanism; } \\
\text { relief from pain, } \\
\text { stress, grief, anger, } \\
\text { and sadness as well } \\
\text { as fulfilling the needs } \\
\text { to fit in, feel } \\
\text { supported, and avoid } \\
\text { withdrawal. low self- } \\
\text { efficacy (quitting), } \\
\text { lack of will power, } \\
\text { weight management }\end{array}$ & $\begin{array}{l}\text { Be "a part } \\
\text { of" } \\
\text { something } \\
\text { and coping } \\
\text { with } \\
\text { feelings of } \\
\text { exclusion } \\
\text { and } \\
\text { difference; }\end{array}$ & $\begin{array}{l}\text { Health care } \\
\text { practitioners } \\
\text { rarely asked } \\
\text { about their } \\
\text { smoking. }\end{array}$ & $\begin{array}{l}\text { Yes- Cost } \\
\text { and } \\
\text { accessibility } \\
\text { as a main } \\
\text { barrier to } \\
\text { NRT use. }\end{array}$ & NRT accessibility \\
\hline $\begin{array}{l}\text { Missen, } \\
\text { [37] }\end{array}$ & $\begin{array}{l}\text { Family members } \\
\text { of current } \\
\text { service users } \\
\text { (acute inpatient, } \\
\text { crisis care, } \\
\text { rehabilitation). } \\
\text { NZ }\end{array}$ & $\begin{array}{l}\text { Flexibility and } \\
\text { support to cut down } \\
\text { consistent, } \\
\text { accessible Smoke- } \\
\text { free information to } \\
\text { be given in the right } \\
\text { form and right time, } \\
\text { family to be } \\
\text { involved, alternative } \\
\text { healthy activities } \\
\text { stop smoking, } \\
\text { education for } \\
\text { families. }\end{array}$ & $\begin{array}{l}\text { Last vice, reward, or } \\
\text { pleasure that people } \\
\text { had left and smoke- } \\
\text { free initiatives were } \\
\text { often viewed in the } \\
\text { context of loss } \\
\text { Smoking as the main } \\
\text { source of activity. }\end{array}$ & None. & $\begin{array}{l}\text { Lack of staff } \\
\text { boundaries in } \\
\text { smoking, staff } \\
\text { attitudes and } \\
\text { approaches, } \\
\text { workload, and } \\
\text { shift structure, } \\
\text { need } \\
\text { consistent } \\
\text { knowledge/trai } \\
\text { ning of NRT } \\
\text { and } \\
\text { behavioural } \\
\text { cessation } \\
\text { techniques. }\end{array}$ & $\begin{array}{l}\text { Yes- } \\
\text { inconsistent } \\
\text { Info given on } \\
\text { NRT and } \\
\text { unavailable, } \\
\text { lack of } \\
\text { availability of } \\
\text { cessation } \\
\text { options; }\end{array}$ & $\begin{array}{l}\text { Inconsistent, } \\
\text { inaccessible } \\
\text { smoke-free } \\
\text { practice and } \\
\text { delivery of smoke } \\
\text { free information } \\
\text { and often } \\
\text { unavailable. } \\
\text { Long waiting lists, } \\
\text { need to provide } \\
\text { and promote } \\
\text { other appropriate } \\
\text { activity to replace } \\
\text { smoking. }\end{array}$ \\
\hline $\begin{array}{l}\text { Snyder } \\
\text { [39] }\end{array}$ & $\begin{array}{l}2 \text { psychiatric } \\
\text { rehab centres } \\
\text { in-mid western } \\
\text { city in US }\end{array}$ & $\begin{array}{l}\text { Influence of non- } \\
\text { smokers, peer } \\
\text { modelling, non- } \\
\text { smoking } \\
\text { environments. }\end{array}$ & $\begin{array}{l}\text { Coping mechanism } \\
\text { for everyday } \\
\text { stressors, no benefit } \\
\text { to quitting, nothing } \\
\text { to look forward to, } \\
\text { more fun. }\end{array}$ & $\begin{array}{l}\text { Social } \\
\text { interaction, } \\
\text { social } \\
\text { majority- } \\
\text { influence of } \\
\text { others. }\end{array}$ & No & No & No \\
\hline
\end{tabular}




\begin{tabular}{|c|c|c|c|c|c|c|c|}
\hline Study & Setting & Facilitators & $\begin{array}{l}\text { Individual } \\
\text { Barriers }\end{array}$ & $\begin{array}{l}\text { Social } \\
\text { Barriers? }\end{array}$ & $\begin{array}{l}\text { Health } \\
\text { Provider } \\
\text { barriers? }\end{array}$ & $\begin{array}{l}\text { NRT } \\
\text { Discussed? }\end{array}$ & $\begin{array}{l}\text { Systemic } \\
\text { barriers } \\
\text { mentioned? }\end{array}$ \\
\hline $\begin{array}{l}\text { Kerr, et al } \\
{[40]}\end{array}$ & $\begin{array}{l}25 \text { PWSMI and } \\
50 \text { health } \\
\text { professionals, } \\
\text { Scotland, UK. }\end{array}$ & $\begin{array}{l}\text { Improve physical } \\
\text { health, increase } \\
\text { disposable income, } \\
\text { role models. }\end{array}$ & $\begin{array}{l}\text { low levels of } \\
\text { motivation and self- } \\
\text { efficacy, mental } \\
\text { health deterioration, } \\
\text { coping resource, lack } \\
\text { knowledge and skills. }\end{array}$ & $\begin{array}{l}\text { Social } \\
\text { influence, } \\
\text { smoking } \\
\text { norm, few } \\
\text { positive } \\
\text { role } \\
\text { models. }\end{array}$ & $\begin{array}{l}\text { lack of support } \\
\text { from MHP (fear } \\
\text { of damaging } \\
\text { relationships, } \\
\text { training, }\end{array}$ & $\begin{array}{l}\text { No, mention } \\
\text { number who } \\
\text { have tried } \\
\text { NRT but no } \\
\text { discussion of } \\
\text { issues }\end{array}$ & $\begin{array}{l}\text { Yes-PWSMI } \\
\text { reluctant to use } \\
\text { mainstream } \\
\text { cessation services, } \\
\text { no guide practice }\end{array}$ \\
\hline Rae, [41] & $\begin{array}{l}\text { Community } \\
\text { mental health } \\
\text { agency, } \\
\text { participants of } 2 \\
\text { cessation } \\
\text { programs. } \\
\text { Ontario, } \\
\text { Canada. }\end{array}$ & $\begin{array}{l}\text { Flexible to needs and } \\
\text { individual choices, } \\
\text { mental health staff } \\
\text { on board to ensure } \\
\text { mental health peer } \\
\text { support/'quit allies' }\end{array}$ & $\begin{array}{l}\text { Low confidence in } \\
\text { quitting, managing } \\
\text { mental health, } \\
\text { ambivalence around } \\
\text { physical health } \\
\text { smoking as self-harm }\end{array}$ & $\begin{array}{l}\text { Environmen } \\
\text { tal factors, } \\
\text { including } \\
\text { difficult life } \\
\text { events and } \\
\text { social } \\
\text { relationship } \\
\text { s }\end{array}$ & No & $\begin{array}{l}\text { Yes- } \\
\text { misinformati } \\
\text { on and self- } \\
\text { stigmatising } \\
\text { myths } \\
\text { around } \\
\text { pharmacolog } \\
\text { y }\end{array}$ & No \\
\hline $\begin{array}{l}\text { Forchuck, } \\
\text { et al [42] }\end{array}$ & $\begin{array}{l}50 \% \text { acute care } \\
\text { settings, 50\% } \\
\text { tertiary care } \\
\text { Southern } \\
\text { Ontario, } \\
\text { Canada. }\end{array}$ & $\begin{array}{l}\text { Distractions, walks, } \\
\text { diversions and group } \\
\text { meetings. }\end{array}$ & $\begin{array}{l}\text { Addiction, smoking } \\
\text { increases energy } \\
\text { levels and } \\
\text { management of } \\
\text { mental health. }\end{array}$ & None & No & None & No \\
\hline $\begin{array}{l}\text { Nawaz et } \\
\text { al. [43] }\end{array}$ & $\begin{array}{l}\text { White, African } \\
\text { American or } \\
\text { Latino from } \\
\text { psychiatric } \\
\text { rehabilitation } \\
\text { agency in } \\
\text { Chicago, US. }\end{array}$ & $\begin{array}{l}\text { Cost of tobacco and } \\
\text { health problems } \\
\text { were motivators to } \\
\text { quit. }\end{array}$ & $\begin{array}{l}\text { Manage stress and } \\
\text { mental health. }\end{array}$ & $\begin{array}{l}\text { Social norm } \\
\text { and } \\
\text { smoking } \\
\text { areas for } \\
\text { social } \\
\text { interaction } \\
\text { reinforced } \\
\text { smoking. }\end{array}$ & $\begin{array}{l}\text { Rewarding } \\
\text { good behaviour } \\
\text { with cigs), lack } \\
\text { of involvement } \\
\text { or } \\
\text { complacency }\end{array}$ & $\begin{array}{l}\text { Yes- } \\
\text { restricted } \\
\text { access to } \\
\text { quit } \\
\text { products. } \\
\text { Misinformati } \\
\text { on about } \\
\text { cessation } \\
\text { products. }\end{array}$ & No \\
\hline $\begin{array}{l}\text { Esterberg } \\
\text {, et al } \\
{[44]}\end{array}$ & $\begin{array}{l}50 \% \text { from a } \\
\text { clinical trials } \\
\text { program, and } \\
50 \% \text { from a } \\
\text { CMHC Atlanta, } \\
\text { USA. }\end{array}$ & $\begin{array}{l}\text { Negative health } \\
\text { consequences of } \\
\text { smoking, financial } \\
\text { burden, problems } \\
\text { with participation in } \\
\text { physical or daily } \\
\text { activity. }\end{array}$ & $\begin{array}{l}\text { Calming effects of } \\
\text { nicotine controlling } \\
\text { mood, when feeling } \\
\text { nervous or irritable, } \\
\text { manage mental } \\
\text { health, relieve } \\
\text { boredom. }\end{array}$ & $\begin{array}{l}\text { Reinforcem } \\
\text { ent of } \\
\text { smoking } \\
\text { from } \\
\text { significant } \\
\text { others. }\end{array}$ & $\begin{array}{l}\text { No doctors, or } \\
\text { treatment } \\
\text { providers had } \\
\text { approached or } \\
\text { encouraged } \\
\text { smoking } \\
\text { cessation. }\end{array}$ & $\begin{array}{l}\text { Yes-Negative } \\
\text { attitudes } \\
\text { about NRT. }\end{array}$ & $\begin{array}{l}\text { Yes- no smoking } \\
\text { cessation } \\
\text { programs }\end{array}$ \\
\hline
\end{tabular}




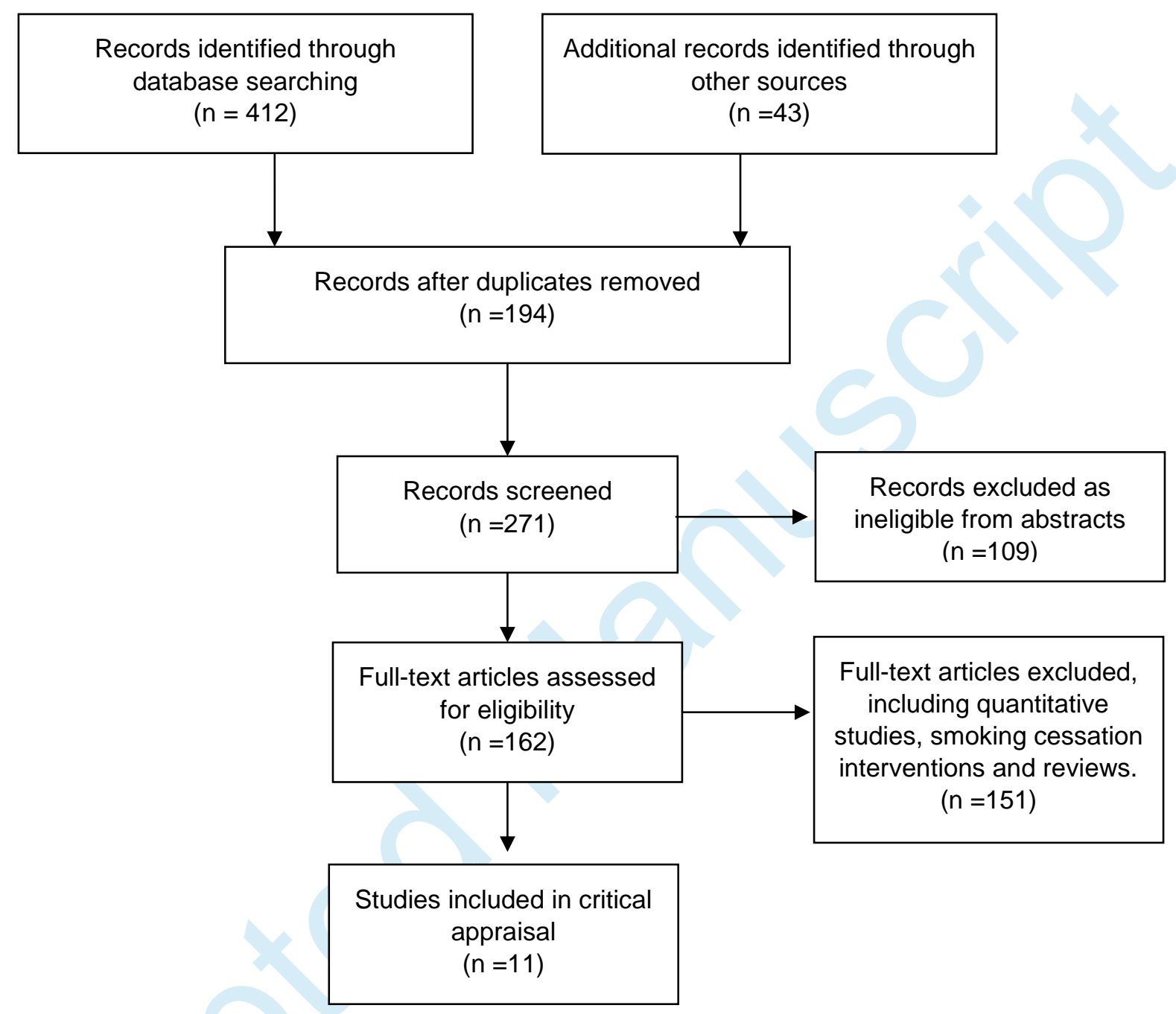

Figure 1. Flow diagram of review process 